\title{
HOSPITAL INFECTIONS RATE AND HEALTH STAFF DENSITY IN A NEONATOLOGY DEPARTMENT
}

\author{
Zorana Djordjevic1, Dragana Ristic ${ }^{2}$, Dragana Savic 2,3, Aleksandra Simovic 2,3, Slobodan M. Jankovic 3,4 \\ ${ }_{1}^{1}$ Department of Hospital Infections Control, Clinical Centre Kragujevac, Kragujevac, Serbia \\ ${ }^{2}$ Neonatology Department, Pediatric Clinic, Clinical Centre Kragujevac, Kragujevac, Serbia \\ ${ }^{3}$ Faculty of Medical Sciences, University of Kragujevac, Kragujevac, Serbia \\ ${ }^{4}$ Clinical Pharmacology Department, Clinical Centre Kragujevac, Kragujevac, Serbia
}

\section{STOPA BOLNIČKIH INFEKCIJA I ANGAŽOVANOST ZAPOSLENIH NA NEONATOLOŠKOM ODELJENJU}

\author{
Zorana Đorđevićl, Dragana Ristić2, Dragana Savić2,3, Aleksandra Simović2,3, Slobodan M. Janković3,4 \\ IOdsek za kontrolu bolničkih infekcija, Klinički centar Kragujevac, Kragujevac \\ ${ }^{2}$ Centar za neonatologiju, Klinika za pedijatriju, Klinički centar Kragujevac, Kragujevac \\ ${ }^{3}$ Fakultet medicinskih nauka, Univerzitet u Kragujevcu, Kragujevac \\ ${ }^{4}$ Služba za kliničku farmakologiju, Klinički centar Kragujevac, Kragujevac
}

\section{ABSTRACT}

Objective. The aim of our study was to compare staffing trends for physicians and nurses with hospital infections (HIs) rate at a neonatology department of tertiary care health facility.

Methods. The prospective cohort study was conducted at Neonatology Department, Clinical Centre Kragujevac, Serbia. The incidences of neonates with HIs were calculated for each of the quarters during the 5-year period. The data about the number and structure of staff for each quarter of the study period were collected from the official work schedule lists of the department.

Results. This study registered a total of 272 HIs occurring in 264 neonates. The incidence rate of patients with HIs was $13.36 \%$ and the incidence density of HIs was 5.85 per 1,000 patient-days. In the observed period the trend of incidence rate of patients with HIs was stable, but the trend of incidence density of HIs was increasing, however without statistical significance. The highest incidence rates of patients with HIs were recorded in the third quarter of all observed years respectively: $17.44 \%$ in $2012,16.74 \%$ in 2013, 23.47\% in 2014, 18.18\% in 2015 and 22.74 in 2016. The average number of nurses in the first shift ranged from 5.0 to 7.0, but in second shift was 3.0 to 4.0 only, and the least number of nurses worked in the third quarter of each year. The average number of physicians in the first shift ranged from 2.33 to 4.47 and they were also the fewest in numbers in the third quarter. We observed strong negative correlation between the average incidence rate of patients with HIs and the average number of nurses in the first shift $(r=-0.977, p=0.023)$.

Conclusion. Optimal nurse and physician staffing of neonatal departments in developing countries and the avoidance of inter-quarter variations in number of staff at duty would decrease the incidence of HIs and probably create overall savings of the hospital budget.

Key words: hospitals; infection; iatrogenic disease; intensive care units, neonatal; health personnel.

\section{SA $\boldsymbol{A}$ ETAK}

Cilj. Cilj ovog istraživanja bio je da se uporede trendovi broja zaposlenih (lekara i medicinskih tehničara) i stope bolničkih infekcija (BI) na neonatološkom odeljenju zdravstvene ustanove tercijarne zdravstvene zaštite.

Metode. Sprovedena je prospektivna kohortna studija $u$ Centru za neonatologiju Kliničkog centra Kragujevac, Republika Srbija. Incidencije novorođenčadi sa BI izračunate su za svaki od kvartala tokom perioda od pet godina. Podaci o broju i organizacionoj strukturi osoblja za svaki kvartal istraživačkog perioda prikupljeni su na osnovu zvaničnih rasporeda rada zaposlenih u centru.

Rezultati. U ovoj studiji registrovano je ukupno 272 BI kod 264 novorođenčeta. Stopa incidencije kod pacijenata sa BI iznosila je 13,36\%, a gustina incidencije BI 5,85 na 1.000 pacijent-dana. $U$ posmatranom periodu trend stope incidencije kod pacijenata sa BI bio je stabilan, ali je trend gustine incidencije BI bio u porastu, mada bez statističke značajnosti. Najveće stope incidencije kod pacijenata sa BI zabeležene su u trecem kvartalu svih posmatranih godina: $17,44 \%$ и 2012, 16,74\% и 2013, 23,47\% и 2014, 18,18\% u 2015. i 22,74 u 2016. godini. Prosečan broj zaposlenih medicinskih sestara u prvoj smeni kretao se od 5,0 do 7,0, dok je u drugoj smeni iznosio od 3,0 do 4,0. Najmanje sestara je radilo u trecem kvartalu svake godine. Prosečan broj lekara u prvoj smeni kretao se od 2,33 do 4,47, a takođe najmanji broj radio je u trećem tromesečju. Uočena je snažna negativna korelaciju između prosečne stope incidencije kod pacijenata sa BI $i$ prosečnog broja medicinskih sestara u prvoj smeni $(r=-0,977, p=0$,023).

Zaključak. Optimalan broj medicinskih sestara $i$ lekara na neonatološkim odeljenjima u zemljama u razvoju, kao $i$ izbegavanje međukvartalnih varijacija u broju zaposlenih može smanjiti incidenciju BI i potencijalno uticati na ukupnu uštedu u budžetu bolnice.

Ključne reči: bolnice; infekcija; jatrogena bolest; jedinica intenzivne nege, neonatalna; zdravstveni radnici. 


\section{INTRODUCTION}

Although national staffing standards for hospitals exist in developed countries, the majority of developing countries either do not have such standards at all, or have some kind of standards which are suboptimal and not based on evidence. Hospital management in developing countries is mostly in a situation to decide about the number of doctors and nurses per occupied bed, constantly looking for the minimum that would not endanger basic patient care, and yet would fit into limited budgets $(1,2)$. Patients in intensive care units are especially vulnerable to insufficient care, and adverse treatment outcomes become more frequent (3). One of the most important complications of treatment is the emergence of hospital infections (HI), which are difficult to treat and linked to increased mortality (4).

Previously published studies showed the existing link between understaffing and increase in HIs rate mostly at wards with adult inpatients, and taking into account the total number of healthcare staff, without an exploration of the staff type (doctors or nurses), educational level or experience (5). However, the study in neonatal intensive care units (NICUs) in USA also showed that NICUs understaffed with nurses for more than one standard deviation from the average were having increased likelihood for HIs with odds ratio of 1.4 (6). Only one study up to now showed seasonal trend of HIs rate (7), but it was not investigated whether these seasonal changes coincide with staffing trends within the hospitals, which usually follow patient demand fluctuations, holiday and budgeting terms (8). Besides, seasonal trends were not explored at neonatology departments.

The aim of our study was to compare staffing trends for physicians and nurses with HIs rate at a neonatology department of a tertiary care health facility.

\section{MATERIAL AND METHODS}

A prospective observational study was conducted during the period from January 2012 to December 2016 at Neonatology Department, Clinical Centre Kragujevac, Serbia. This department has 30 beds, half of them belong to the NICU, and the other half to special care. About 350450 critically ill neonates are admitted to this department annually, amounting up to 9-1000 patients-days.

The diagnosis and classification of anatomic localization of HIs was determined according to the criteria from the Centers for Disease Control and Prevention (CDC), Atlanta, USA (9). These infections were defined as the occurrence of infection after the admission to the hospital, without evidence that the infection was present or incubating $(\leq 48 \mathrm{~h})$ at admission. Surveillance of HIs was done by the team made by a doctor and three nurses, trained in infection control. The members of the team did not change during the study. Surveillance of infections is done daily in cooperation with a relevant doctor and includes: clinical examination of patients and review of their files.

The incidence of patients with HIs was calculated as the number of neonates with an infection in the reporting period divided by all neonates included in the study for that period (x100). Incidence density of HIs was calculated as the number of HIs in that year divided by realized hospital days (patient-days) for that year (x1000).

The efforts of controlling infection at this department included: the implementation of contact isolation for neonates with HIs caused by a multidrug- resistant organism, wall dispensers with alcohol hand rubs for each incubator separately, and training of staff in prevention of HIs.

The data about number and structure of staff for each day of the study period were collected from the official work schedule lists of the Neonatology Department. Physicians and nurses at this department work in three 8hour shifts, and the average number of employees per shift was calculated for each quarter of a year. The average number of physicians during the first shift varied, while the second and night shifts were "covered" by only one doctor each. In regard to the nurses, the number of those engaged varied during the first and second shift, while during the night shift it was always 3 nurses that worked.

The study was approved by the Ethics Committee of the Clinical Centre Kragujevac, Serbia.

The data were analyzed using descriptive statistical methods including measures of central tendency (mean), measures of variability (standard deviation), and relative numbers. Trends analysis was carried out using linear regression. The rate of change in the trends was calculated from linear regression as the percentage increase or decrease on annual basis. The difference between the measured parameters in the two groups was tested by the Student t-test. The presence or absence of an association was tested by Pearson correlation coefficient (r). The values of $p<0.05$ were considered statistically significant. The analyses were performed by the SPSS software, version 18 (Chicago, IL, USA)

\section{RESULTS}

In the observed period at the Neonatology Department 1991 newborns were admitted to hospital treatment in total, with an average gestational age of 36.09 \pm 3.07 weeks and birth weight of $2649.09 \pm 902.87$ grams. There were more male $(n=1139 ; 57.20 \%)$ than female subjects. In accordance with the adopted criteria a total of 272 HIs occurred in 264 neonates, so $13.95 \%$ of infants developed at least one HIs. The incidence rate of patients with HIs for the whole period was $13.36 \%$ and the incidence density of NIs was 5.85 per 1,000 patient-days. However, in the 
period covered by this study a stable trend of incidence rate of patients with HIs was recorded and an increasing trend of incidence density of HIs, but without statistical significance $(\mathrm{p}>0.05)$ (Table 1).
The dominant anatomical localizations of HIs at this department (nearly 95\%) were pneumonia and urinary tract infection $(71.32 \%$ vs. $23.53 \%$, respectively) while other infections were rarely recorded (Table 2).

Table 1. Incidence rate of hospital infections in Neonatology Department, Clinical Centre Kragujevac, Serbia, 2012-2016.

\begin{tabular}{|c|c|c|c|c|c|c|c|c|}
\hline Variables & 2012 & 2013 & 2014 & 2015 & 2016 & $\mathbf{r}^{2}$ & p value & Trend \\
\hline Patients with HIs & 55 & 51 & 53 & 52 & 53 & & & \\
\hline HIs & 56 & 52 & 55 & 53 & 56 & & & \\
\hline $\begin{array}{l}\text { Incidence patients with } \\
\text { HIs* }\end{array}$ & 14.99 & 11.23 & 12.96 & 13.90 & 13.70 & 0.000 & 0.987 & Stable \\
\hline Incidence density of HIs** & 5.84 & 5.35 & 6.05 & 5.84 & 6.17 & 0.336 & 0.305 & Increasing \\
\hline
\end{tabular}

HI- hospital infection

* was calculated as number of patients with HI per 100 patient/year

** was calculated as number of HI per 1,000 patient-days/year

Table 2. Anatomic localization of hospital infections in the Neonatology Department, Clinical Centre Kragujevac, Serbia, 2012-2016.

\begin{tabular}{|l|c|c|c|c|c|c|}
\hline Infection & $\begin{array}{c}\mathbf{2 0 1 2} \\
\mathbf{n ~ ( \% )}\end{array}$ & $\begin{array}{c}\mathbf{2 0 1 3} \\
\mathbf{n}(\mathbf{\%})\end{array}$ & $\begin{array}{c}\mathbf{2 0 1 4} \\
\mathbf{n}(\mathbf{\%})\end{array}$ & $\begin{array}{c}\mathbf{2 0 1 5} \\
\mathbf{n}(\mathbf{\%})\end{array}$ & $\begin{array}{c}\mathbf{2 0 1 6} \\
\mathbf{n}(\mathbf{\%})\end{array}$ & Total \\
\hline Urinary tract & $15(26.79)$ & $6(11.54)$ & $7(12.73)$ & $16(30.19)$ & $20(35.71)$ & $64(23.53)$ \\
\hline Pneumonia & $35(62.50)$ & $43(82.69)$ & $48(87.27)$ & $35(66.04)$ & $33(58.93)$ & $194(71.32)$ \\
\hline Bloodstream & $4(7.14)$ & $3(5.77)$ & 0 & $1(1.89)$ & 0 & $8(2.94)$ \\
\hline Central nervous system & 0 & 0 & 0 & 0 & $2(3.57)$ & $2(0.74)$ \\
\hline Skin and soft tissue & $2(3.57)$ & 0 & 0 & $1(1.89)$ & $1(1.79)$ & $4(1.47)$ \\
\hline Total & $56(100.0)$ & $52(100.0)$ & $55(100.0)$ & $53(100.0)$ & $56(100.0)$ & $272(100.0)$ \\
\hline
\end{tabular}

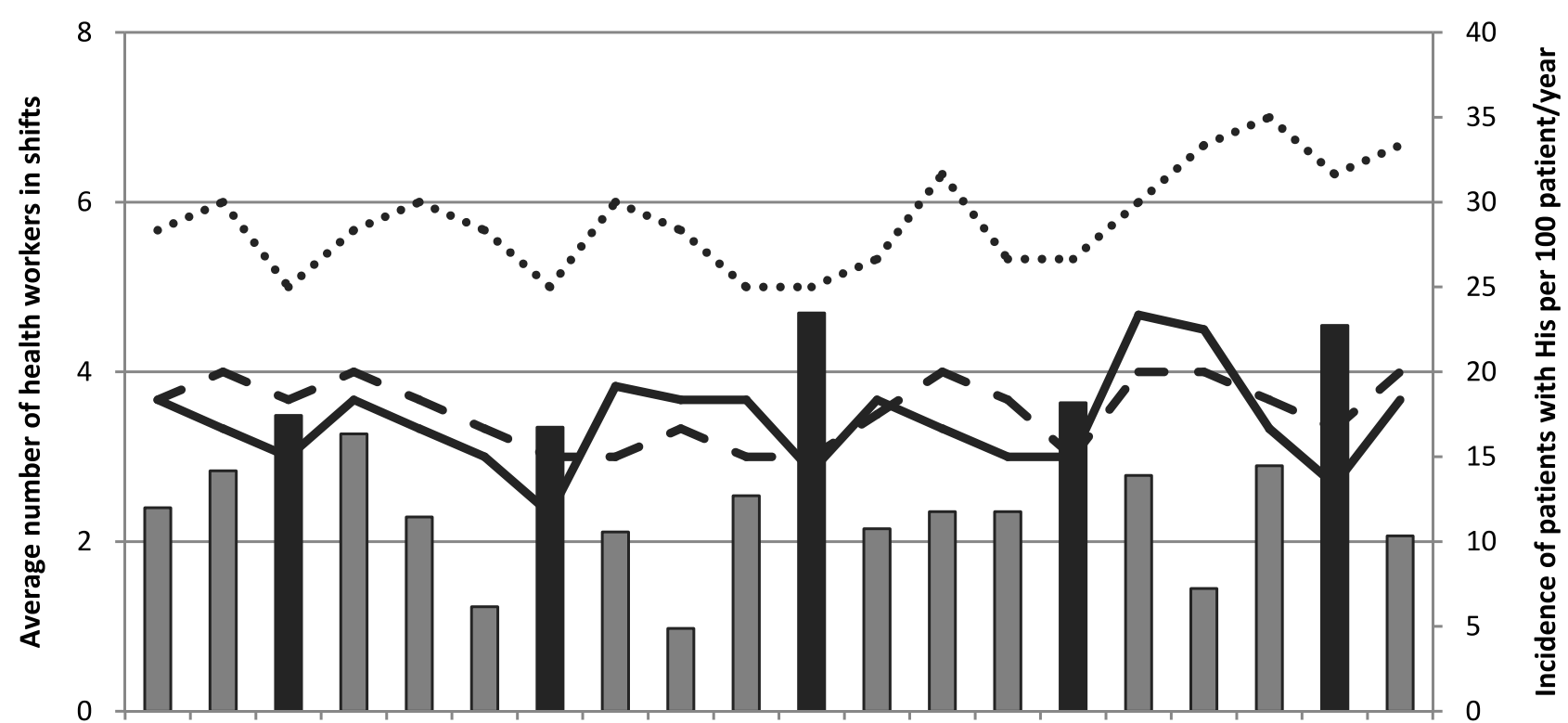

20122012201220122013201320132013201420142014201420152015201520152016201620162016

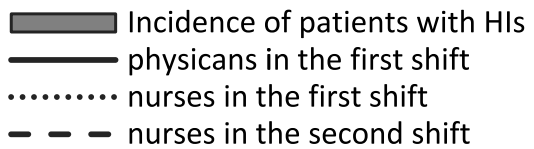

Figure 1. Incidence rate of patients with infections and average number of health workers in shifts per day at the Neonatology Department, Clinical Centre Kragujevac, Serbia, 2012-2016. X-axis: quartiles of years 2012-2016. 
Figure 1 shows the relationship between the incidence rate of patients with HIs and the number of engaged health workers at the Neonatology Department during the study period, as shown by quarters. The average number of nurses in the first shift ranged from 5.0 to 7.0 , but in the second shift was from 3.0 to 4.0. It was noted that the least average number of nurses worked in the third quarter of each year. The average number of physicians in the first shift ranged from 2.33 to 4.47 and they were also the fewest in numbers in the third quarter. Simultaneously, the highest incidence rates of patients with HIs were recorded in the third quarter of all observed years respectively: $17.44 \%$ in $2012,16.74 \%$ in $2013,23.47 \%$ in 2014 , $18.18 \%$ in 2015 and 22.74 in 2016 (Figure 1).

We observed a strong negative correlation between the average incidence rate of patients with HIs and the average number of nurses in the first shift $(r=-0.977$, $\mathrm{p}=0.023$ ), while for the nurses in the second shift the correlation was at a margin of statistical significance $(r=-$ $0.942, \mathrm{p}=0.058)$. There was no association between the incidence rate and the average number of physicians in the first shift $(r=-0.806, p=0.149)$ (data not showed).

\section{DISCUSSION}

HIs are frequent in Neonatology Departments and NICUs due to extensive use of invasive diagnostic and therapeutic procedures. Among others, peripheral and central venous catheter insertion and mechanical ventilation pose significant risks for infection, and health care staff is responsible for maintaining sterility during these manipulations. Our research has shown that the most common HIs was pneumonia with a share of $71.32 \%$ of all registered infections, which is consistent with results of other studies (10). However, at many NICUs health workers in addition to caring for patients have a myriad of additional responsibilities: transporting infants to the other health facilities, accompanying infants to the operating room or radiology departments, carrying blood samples to laboratory, etc. All this results with additional workload for health workers and increases chances of errors and adverse events.

When NICUs are understaffed, nurses and physicians are unable to perform essential caretaking tasks, or such tasks can't be performed in a timely manner. The quality of care decreases and the incidence of errors and adverse events grows in such situations (11). The care of the mechanically ventilated patients is especially highly workforce demanding, and it was noted that the optimal number of nurses per ventilated patient decreases chances of ventilator-associated pneumonia for $58 \%$ (12). Not only the patients suffer from the understaffing: health workers frequently develop job dissatisfaction, stress, burnout syndrome, and the intention to quit their job. However, suffering of the health workers inevitably leads to even further decrease of the quality of care and increase in HIs rate (13), and the vicious circle is closed.
Nurses are essential for providing bedside patient care which may directly impact infection prevention, but they also play an important role in care coordination and creating a safe environment for patients, both of which are related to infection control and prevention $(14,15)$. Therefore, it is important to understand the relationship between nurse staffing and HAIs. Researchers have been studying hospital nurse staffing in Neonatology Department in relation to the incidence rates of patients with HIs and showed that there was an increase of HIs in the third quarter of each year when, due to the use of holidays the number of nurses decreased. The incidence rates of patients with HIs in the third quarter ranged from 16.74 to 23.47 , the average number of nurses in the first shift ranged from 5.0 to 6.33 , and in the second shift was 3.0 to 3.67. In the third shift it was always tree nurses working, so this has not been considered. Strong negative correlation was found only between the average incidence rate of patients with HIs and the average number of nurses in the first shift. On the other hand, the average number of physicians in the first shift ranged from 2.33 to 3.0, while during the second and night shifts one doctor always worked and there was no correlation between the number of physicians and the incidence rates of HIS.

Although studies of correlation between staffing and HIs incidence rate in NICUs are missing, the studies of this relation in adult ICUs produced a growing body of evidence which relates higher ratio of registered nursing staff and patients to improved safety, decreasing the number of HIs and bearing better outcomes for patients (16-18). Critically ill patients such as the newborns demand increased nurse staffing resources and nurses who have specialist knowledge and skills. Appropriate nurse staffing in NICU units may improve the quality of care of critically ill children.

Nurses in NICU are engaged the most about the very low-birth-weight infants who make high-risk population for development the HIs, which are further associated with higher mortality and costs. The occurrence of infection more than doubles the mortality rate of these infants (19). Payne al al. (20), state that among very low-birth-weight infants who survived for 3 days, $13.8 \%$ of those with HIs died compared with $5.5 \%$ without infection, and infants who develop an infection stayed 4 to 7 days longer than those without, which puts additional burden on medical staff and increases costs of treatment.

The main limitation of our study is its uni-centricity, as it was conducted in only one hospital with a small sample size and minimum variability within the institution, so many important influences on outcomes may be masked. In addition, local character of the study precludes cross institutional comparison and restricts the study's generalizability (22).

Our study showed that even seasonal variations in nurse and pediatrician staffing of neonatology departments are followed with the increase in HIs rate, especially that of ventilator-associated pneumonia. As 
already explained, patients in NICUs are especially sensitive to insufficient care, and HIs are among the most frequent complications of such situation. Managers of hospitals in developing countries should be aware of this fact and invest in appropriate staffing. The cost of one HIs in NICU is as high as 16,800 US dollars (21), and just one avoided infection can provide full annual salaries for 10 nurses in Serbia and other developing countries.

In conclusion, optimal staffing of neonatal departments with physicians and nurses in developing countries and avoidance of inter-quarter variations in the number of staff at duty would decrease the incidence of HIs and probably create overall savings of the hospital budget.

\section{REFERENCES}

1. Couraud S, Chan S, Avrillon V, et al. How practical guidelines can be applied in poor countries? Example of the introduction of a bronchoscopy unit in Cambodia. Rev Pneumol Clin 2013; 69: 244-9.

2. Arnold R, van Teijlingen E, Ryan K, Holloway I. Understanding Afghan healthcare providers: a qualitative study of the culture of care in a Kabul maternity hospital. BJOG 2015; 122: 260-7.

3. Clarke SP. Nurse staffing in acute care settings: research perspectives and practice implications. Jt Comm J Qual Patient Saf 2007; 33: 30-44.

4. Shehab El-Din EM, El-Sokkary MM, Bassiouny MR, Hassan R. Epidemiology of neonatal sepsis and implicated pathogens: A study from Egypt. Biomed Res Int 2015; 2015: 509484

5. Rogowski JA, Staiger D, Patrick T, Horbar J, Kenny M, Lake ET. Nurse staffing and NICU infection rates. JAMA Pediatr 2013; 167: 444-50.

6. Daud-Gallotti RM, Costa SF, Guimarães T, et al. Nursing workload as a risk factor for healthcare associated infections in ICU: a prospective study. PLoS One 2012; 7: e52342.

7. Kaier K, Mutters NT, Frank U. Bed occupancy rates and hospital-acquired infections - should beds be kept empty? Clin Microbiol Infect 2012; 18: 941-5.

8. Seo S, Spetz J. Demand for temporary agency nurses and nursing shortages. Inquiry 2013; 50: 216-28.

9. Horan TC, Andrus M, Dudeck MA. CDC/NHSN surveillance definition of health care-associated infection and criteria for specific types of infections in the acute care setting. Am J Infect Control 2008; 36: 309-32.

10. Tekin R, Dal T, Pirinccioglu H, Oygucu SE. A 4-year surveillance of device-associated nosocomial infections in a neonatal intensive care unit. Pediatr Neonatol 2013; 54: 303-8.
11. Dowell D, Manwell LB, Maguire A, et al.; MEMO Investigators. Urban outpatient views on quality and safety in primary care. Healthc Q 2005; 8: 2-8.

12. Schwab F, Meyer E, Geffers C, Gastmeier P. Understaffing, overcrowding, inappropriate nurse: ventilated patient ratio and nosocomial infections: which parameter is the best reflection of deficits? J Hosp Infect 2012; 80: 133-9.

13. Hugonnet S, Harbarth S, Sax H, Duncan RA, Pittet D. Nursing resources: a major determinant of nosocomial infection? Curr Opin Infect Dis 2004; 17: 329-33.

14. Weaver SJ, Weeks K, Pham JC, Pronovost PJ. On the CUSP: Stop BSI: evaluating the relationship between central line-associated bloodstream infection rate and patient safety climate profile. AJIC 2014; 42: 203-8.

15. Kelly D, Kutney-Lee A, Lake ET, Aiken LH. The critical care work environment and nurse-reported health care-associated infections. Am J Crit Care 2013; 22: 482-8.

16. McGahan M, Kucharski G, Coyer F. Nurse staffing levels and the incidence of mortality and morbidity in the adult intensive care unit: a literature review. Aust Crit Care 2012; 25: 64-77.

17. Bray K, Wren I, Baldwin A, et al. Standards for nurse staffing in critical care units determined by: The British Association of Critical Care Nurses, The Critical Care Networks National Nurse Leads, Royal College of Nursing Critical Care and In-flight Forum. Nurs Crit Care 2010; 15: 109-11.

18. Cimiotti JP, Aiken LH, Sloane DM, Wu ES. Nurse staffing, burnout, and health care-associated infection. Am J Infect Control 2012; 40: 486-90.

19. Stoll BJ, Hansen N, Fanaroff AA, et al. Late-onset sepsis in very low birth weight neonates: the experience of the NICHD Neonatal Research Network. Pediatrics 2002; 110: 285-91.

20. Payne NR, Carpenter JH, Badger GJ, Horbar JD, Rogowski J. Marginal increase in cost and excess length of stay associated with nosocomial bloodstream infections in surviving very low birth weight infants. Pediatrics 2004; 114: 348-55.

21. Donovan EF, Sparling K, Lake MR, et al.; Ohio Perinatal Quality Collaborative. The investment case for preventing NICU-associated infections. Am J Perinatol. 2013; 30: 179-84.

22. Shang J, Stone P, Larson E. Studies on nurse staffing and health care-associated infection: methodologic challenges and potential solutions. Am J Infect Control 2015; 43: 581-8. 